Supporting Information for the Environmental Science and Technology article:

\title{
Oxidation of Antibacterial Molecules by Aqueous Ozone: Moiety-Specific Reaction Kinetics and Application to Ozone-Based Wastewater Treatment
}

\author{
Prepared on December 14, 2005 \\ Michael C. Dodd, Marc-Olivier Buffle, and Urs von Gunten* \\ Swiss Federal Institute of Aquatic Science and Technology (EAWAG) \\ Duebendorf, Switzerland CH-8600
}

Twenty-nine pages of Supporting Information, including 5 narratives, 3 tables, and 14 figures:

Text S1. Mechanisms of antibacterial compounds' biochemical activities and relevance to target sites at which $\mathrm{O}_{3}$ is expected to react with parent antibacterial molecules.

Text S2. Chemical reagents.

Text S3. Measurement of apparent second-order rate constants for $\mathrm{O}_{3}$ and $\bullet \mathrm{OH}$ reactions

Text S4. Wastewater matrix experiments.

Text S5. Estimation of transformation efficiencies and $\mathrm{f}_{{ }_{\circ \mathrm{OH}, \mathrm{M}}}$ for RX, AZ, AM, and LM

Table S1. $\mathrm{p} K_{\mathrm{a}}$ values and corresponding source references for each antibacterial substrate

Table S2. $\mathrm{p} K_{\mathrm{a}}$ values and corresponding source references for each substructure model substrate

Table S3. Second-order rate constants $\left(\mathrm{M}^{-1} \mathrm{~s}^{-1}\right)$ for reactions of $\mathrm{O}_{3}$ with substructure model substrates

Figure S1. Maximum single-compound concentrations of various antibacterial classes detected in municipal wastewater systems and surface waters, in the context of minimum reported clinical MIC values for sensitive bacterial reference strains.

Figure S2. Biochemical model for mechanism of macrolide antibacterial activity

Figure S3. Biochemical mechanism of sulfonamide antibacterial activity

Figure S4. Biochemical model for mechanism of fluoroquinolone antibacterial activity

Figure S5. Biochemical mechanism of dihydrofolate reductase (DHFR) inhibitor antibacterial activity.

Figure S6. Biochemical model for mechanism of lincosamide antibacterial activity

Figure S7. Biochemical mechanism of $\beta$-lactam antibacterial activity (depicted for penicillin $\mathrm{G}$ )

Figure S8. Biochemical model for primary mechanism of tetracycline antibacterial activity

Figure S9. Biochemical model for mechanism of glycopeptide antibacterial activity

Figure S10. Biochemical model for mechanism of aminoglycoside antibacterial activity

Figure S11. Calculated $t_{1 / 2}$ values for the apparent transformation of model antibacterial substrates by $\mathrm{O}_{3}$, in comparison to corresponding estimated half-lives for reaction of $\mathrm{O}_{3}$ with the targeted functional moieties associated with each substrate's biochemical activity

Figure S12. Transformation of ASMX during ozonation of Kloten-Opfikon wastewater

Figure S13. Correlations of predicted substrate transformation with measured values

Figure S14. Comparison of $\mathrm{f}_{\cdot \mathrm{OH}, \mathrm{M}(\tau)}$ values calculated from indirect determinations of $\mathrm{O}_{3}$ exposure with those calculated from direct measurements of $\mathrm{O}_{3}$ exposure 
Text S1. Mechanisms of antibacterial compounds' biochemical activities and relevance to target sites at which $\mathrm{O}_{3}$ is expected to react with parent antibacterial molecules.

Macrolides. Macrolide antibacterials are believed to derive their biochemical activity from specific hydrogen bonding with various nucleobases and phosphodiester linkages in the peptidyl transferase cavity of bacterial 23S rRNA (Figure S2) (1). The bonding interaction most likely to be interrupted by direct reaction with $\mathrm{O}_{3}$ is that involving each macrolide's characteristic tertiary amine (Figure S2), which is expected to be highly reactive toward $\mathrm{O}_{3}(2,3)$. Oxidation of the tertiary amine via formation of an aminoxide or via demethylation (3) should prevent its hydrogen bonding with 23S rRNA, leading to reduction or elimination of each parent macrolide's antibacterial activity. Macrolides with fifteen- and sixteen-membered macrolactone rings generally possess additional moities that can be expected to react rapidly with $\mathrm{O}_{3}$. For example azithromycin $(\mathrm{AZ}-$ a fifteen-membered macrolide - shown in Table 1 within the main text) and tylosin (TYL - a sixteen-membered macrolide - shown in Table 1) contain an additional tertiary amine and a conjugated diene, respectively. Oxidation of azithromycin's (AZ) heterocyclic nitrogen would likely be sufficient to impair the parent structure's antibacterial activity if such a reaction resulted in rupture of its macrolactone ring (e.g., via dealkylation of the nitrogen atom (3)). This would presumably result in interruption of the specific stereochemistry necessary for appropriate hydrogen bonding between the AZ structure and bacterial rRNA (Figure S2). Similarly, reaction of $\mathrm{O}_{3}$ with tylosin's (TYL) diene moiety should lead to impairment of the parent structure's antibacterial activity, where ozonolysis of one or both olefinic bonds would result in rupture of TYL's macrolactone ring (4).

Sulfonamides. All sulfonamide antibacterial structures are derivatives of $p$-aminobenzenesulfonamide - a structural analog of $p$-aminobenzoic acid ( $p \mathrm{ABA})$ - and are differentiated only by the particular Rsubstituent attached to the sulfonamide nitrogen (Figure S3). These compounds derive their antibacterial activity from antagonistic competition with $p \mathrm{ABA}$ for dihydropteroate synthase enzyme during bacterial synthesis of dihydropteroic acid (the precursor to folic acid) (Figure S3) (5). The p-sulfonyl aniline moiety, in particular, is responsible for each sulfonamide's interference with bacterial folate synthesis 
(Figure S3). This moiety should present a very favorable target for $\mathrm{O}_{3}$, since aromatic amines are generally very reactive toward $\mathrm{O}_{3}(2,6,7)$. Sulfonamides' R-substituent moieties (e.g., isoxazole in the case of sulfamethoxazole, SMX - shown in Table 1 within the main text), can also be expected to react with $\mathrm{O}_{3}$. These latter reactions will not lead to oxidation of the functional moiety responsible for the parent structures' antibacterial potency. However they may indirectly influence the parent molecules' antibacterial activity either positively or negatively, by altering the parent molecule's bioavailability.

Fluoroquinolones. Fluoroquinolones are believed to derive their biochemical activity from several specific hydrogen-bonding and charge interactions with relaxed bacterial DNA in the presence of DNA gyrase enzyme (Figure S4) (8). According to the accepted model for fluoroquinolone-DNA binding, the characteristic quinolone moiety is responsible for these interactions (Figure S4). Oxidation of this moiety by $\mathrm{O}_{3}$ (as expected on the basis of relatively fast reaction kinetics measured for the structurally-similar substrate uracil-6-carboxylic, or isoorotic, acid (9)) should therefore lead to a reduction or elimination of fluoroquinolones' antibacterial potencies. However, the heterocyclic substituent groups (typically piperazine derivatives, as for $\mathrm{CF}$ and $\mathrm{EF}$ - shown in Table 1 within the main text) attached to many fluoroquinolones' quinolone moieties do not appear to be essential to fluoroquinolone antibacterial activity. For example, first-generation quinolones such as nalidixic acid lack the heterocycle, but still exhibit considerable antibacterial potency (10). Thus, oxidation of the $\mathrm{N}(4)$ amine - expected on the basis of secondary and tertiary amines' generally high reactivities toward $\mathrm{O}_{3}(2,3)$ - may not contribute to a significant reduction in CF's antibacterial activity.

Dihydrofolate Reductase (DHFR) Inhibitors. DHFR inhibitors (e.g., trimethoprim, TMP - shown in Table 1 within the main text) inhibit bacterial folate synthesis via competition with dihydrofolate for DHFR enzyme (hence TMP's common role as a synergist to the sulfonamide, SMX) (Figure S5) (5). The diaminopyrimidine structure represents the active portion of these antibacterial molecules, where the protonated nitrogen atom, N(1), of the heterocyclic ring (Figure S5) participates in charge interactions with DHFR (11). Oxidation of the 2,4-diaminopyrimidine structure - anticipated on the basis of 
pyrimidine structures' generally high reactivity toward $\mathrm{O}_{3}(9)$ - is therefore likely to yield a reduction in the parent structure's antibacterial potency. TMP's 3,4,5-trimethoxytolyl moiety will also likely react relatively rapidly with $\mathrm{O}_{3}(12)$. As in the case of sulfonamide R-substituent oxidation, this latter reaction may indirectly influence the parent molecule's antibacterial activity by altering its bioavailability.

Lincosamides. Lincosamides interact with bacteria via hydrogen-bonding to specific nucleotides in bacterial 23S rRNA, leading to inhibition of the bacteria cells' ability to synthesize proteins (Figure S6) (1). None of the functional moieties directly responsible for lincosamide antibacterial activity are expected to react appreciably with $\mathrm{O}_{3}$. However, $\mathrm{O}_{3}$ is likely to oxidize the lincosamide thioether moiety to its sulfoxide derivative $(13,14)$. In the case of lincomycin (LM - shown in Table 1 within the main text), this reaction should lead to LM-sulfoxide, which is known to possess significantly lower antibacterial potency than the parent structure (15) - presumably due to interruption of requisite intermolecular hydrogen bonding patterns at adjacent hydroxyl and methyl groups by thioether oxidation (Figure S6). It is unclear whether oxidation of LM's pyrrolidine moiety would produce such an effect, since the pyrrolidine moiety is spatially and electronically isolated from most of LM's biochemicallyrelevant functional moieties (Figure S6).

$\beta$-lactams. $\beta$-lactams (including the major penicillin and cephalosporin sub-classes) derive their antibacterial activities from the fused $\beta$-lactam ring system, which operates via sequestration of bacterial peptidoglycan transpeptidase enzyme, leading to disruption of bacterial cell wall synthesis (Figure S7) $(5,16)$. The $\beta$-lactam ring itself is unlikely to be reactive toward $\mathrm{O}_{3}$. However, $\mathrm{O}_{3}$ can be expected to react with $\beta$-lactams' characteristic thioether moieties (see PG and CP - Table 1 in the main text). Oxidation of the thioether by $\mathrm{O}_{3}$ is known to lead to high yields (>95\%) of many $\beta$-lactams' $R$ - and $S$-sulfoxide enantiomers (in $R: S$ ratios ranging from 1:4 to 24:1) (13). Although $S$-sulfoxide analogues of $\beta$-lactams exhibit negligible antibacterial activities, their $R$-sulfoxide analogues are still quite potent $(17,18)$, suggesting that oxidation of the thioether by $\mathrm{O}_{3}$ may not be sufficient to eliminate the parent $\beta$-lactam compounds' antibacterial activities. Oxidation of the double bond present in cephalosporin structures 
(e.g., cephalexin, $\mathrm{CP}$ - shown in Table 1 within the main text) - most likely leading either to ozonolytic cleavage or epoxidation $(4,19)$ - may also be insufficient to eliminate the parent structure's antibacterial properties, since the $\beta$-lactam ring would not likely be disrupted by such a reaction. Similarly, oxidation of CP's primary amine (Table 1) is not expected to lead to significant reduction of the parent structure's antibacterial activity.

Tetracyclines. The antibacterial activities of tetracycline antibacterials appear to be derived primarily from direct or indirect (metal cation-mediated) electrostatic charge interactions between the keto and hydroxyl oxygens on the underside of the tetracycline molecule and the oxygens of various internucleotide phosphodiester linkages on the 16S rRNA helix contained within the 30S subunit of the bacterial ribosome (Figure S8) (20). Oxidation of the tetracyclic system by $\mathrm{O}_{3}-$ expected on the basis of its activated unsaturated and aromatic character $(2,4,21,22)$ - should lead to reduction of the parent molecules' antibacterial properties, since such reactions would likely lead to extensive modification of the relevant aromatic and olefinic moieties $(4,22)$. However, oxidation of a the tertiary amine moiety appears less likely to yield a significant reduction in antibacterial potency of the parent molecule, since this trialkylamine moiety is spatially isolated from most biochemically-relevant tetracycline functional moieties and not essential to the tetracyclines' modes of action (Figure S8)

Glycopeptides. Glycopeptides (e.g., vancomycin, VM - shown in Table 1 within the main text) are believed to derive their antibacterial activity from sequestration of specific subunits of the peptidoglycan used in cell wall synthesis (Figure S9) (23). Although none of the amide moieties directly involved in the hydrogen-bonding responsible for these interactions should be appreciably reactive toward $\mathrm{O}_{3}(24)$, several of the adjacent aromatic moieties (Table 1 ) should be highly reactive $(2,12)$. One would expect that ozonation of VM's phenol or trimethoxybenzyl moieties by $\mathrm{O}_{3}$ should lead to ring cleavage, oxidation to quinone structures, or formation of oxyl radicals (the latter of which could foreseeably crosslink with proximal components of the VM structure) (22,25). Each of these structural modifications would likely lead at least to impairment, if not elimination of VM's antibacterial activity, via interruption 
of the specific VM stereochemistry necessary for binding of bacterial peptidoglycan (Figure S9). Oxidation of the secondary $\mathrm{N}$-methylleucine moiety by $\mathrm{O}_{3}$ (presumably leading to hydroxylation or dealkylation of the amine (26)) may also lead to disruption of hydrogen bonding at the adjacent amide (Figure S9). However, oxidation of the primary vancosamine will not likely lead to sufficient disruption of stereochemistry to substantially diminish VM's antibacterial potency, as a consequence of the vancosamine moiety's isolation from VM's biochemically-relevant amide moieties (Figure S9).

Aminoglycosides. Aminoglycosides - which are inhibitors of bacterial protein synthesis - derive much of their antimicrobial activity from charge interactions with nucleobase and phosphodiester functional groups in bacterial rRNA (27). One proposed binding scheme - developed with streptomycin as a model - suggests that these interactions involve various hydroxyl and amine groups within the typical aminoglycoside structure (Figure S10). Aminoglycosides also contribute to disruption of cell walls; an attribute apparently derived in large part from their ability to displace $\mathrm{Mg}^{2+}$ and $\mathrm{Ca}^{2+}$ from outer membrane-associated lipopolysaccharide bridges (28). Oxidation of an aminoglycoside's primary amine moieties by $\mathrm{O}_{3}$ (e.g., to nitro groups, aminoxides, or via deamination (14)) would presumably prevent the bacterial rRNA hydrogen bonding and cationic charge-interactions from which aminoglycoside antibacterial activity is largely derived (Figure S10), in turn leading to reduction or elimination of the parent compounds' antibacterial potencies.

Text S2. Chemical reagents

Commercially-available antibacterial substrates and substructure model substrates were purchased from Sigma-Aldrich, with the exception of cephalexin (CP) hydrate - which was purchased from MP Biomedicals. Azithromycin (AZ) dihydrate was a gift from Pfizer, Inc. 2,4-diamino-5-methyl pyrimidine (DAMP) - produced by Daniels Fine Chemicals, Ltd., and 4-aminophenyl methyl sulfone - produced by Sigma-Aldrich, were gifts from Professor Ching-Hua Huang, Georgia Institute of Technology, Atlanta, GA. N(4)-acetyl-sulfamethoxazole (ASMX) was synthesized as described by Göbel et al. (29). All 
substrates were of $95 \%$ purity or higher, with the exception of ASMX - which was 70\% pure. Other chemicals (e.g., buffers, $\mathrm{H}_{2} \mathrm{O}_{2}$, reducing agents, etc.) were of reagent grade quality or better. $\mathrm{O}_{3}$ stock solutions were produced as described previously (30), and standardized according to direct $\mathrm{O}_{3}$ absorbance at $\lambda=258 \mathrm{~nm}$ (using $\varepsilon \cong 3000 \mathrm{M}^{-1} \mathrm{~cm}^{-1}$ ). Stock solutions of antibacterials and substructure models were prepared in Nanopure or Milli-Q water. Acetone and acetonitrile $-\bullet \mathrm{OH}$ scavengers which should not accelerate radical-chain $\mathrm{O}_{3}$ decay in the aqueous systems typical of this study (31-33) - were used to facilitate preparation of several poorly soluble reactant stock solutions for $\mathrm{O}_{3}$ rate constant determinations. Acetone and acetonitrile concentrations never exceeded $1 \%$ by volume, so co-solvent effects should have been negligible (34). Solutions used for determination of $\bullet \mathrm{OH}$ rate constants and for municipal wastewater experiments contained no co-solvents.

Text S3. Measurement of apparent second-order rate constants for $\mathrm{O}_{3}$ and $\bullet \mathrm{OH}$ reactions Method I ( $\mathrm{O}_{3}$ kinetics): Used for $\mathrm{RX}, A Z, A M, C H, C H M, D M C H, E P C$, and MP (Tables 1 and 2 within the main text). Rate constants for model substrates which react relatively slowly with $\mathrm{O}_{3}$, but do not absorb UV radiation appreciably at $\lambda=258 \mathrm{~nm}$ were measured by directly following the consumption of $\mathrm{O}_{3}$ at this wavelength. These experiments were conducted under conditions of excess substrate, where [substrate $]_{0}:\left[\mathrm{O}_{3}\right]_{0}$ was at least 10:1 (typically 20:1 or greater) in all cases. Pseudo-first-order rate constants determined from plots of $\ln \left(\left[\mathrm{O}_{3}\right] /\left[\mathrm{O}_{3}\right]_{0}\right)$ vs. time were linear $\left(\mathrm{r}^{2} \geq 0.98\right)$ in all cases. A stopped-flow spectrophotometry system was constructed in house to permit measurement of pseudo-first-order rate constants $k_{\mathrm{O}_{3}, \text { obs, } \mathrm{M}}^{\prime}$ up to approximately $2.3 \mathrm{~s}^{-1}$. Solutions of substrate and $\mathrm{O}_{3}$ were prepared at 100 to 200 $\mu \mathrm{M}$ and 10 to $20 \mu \mathrm{M}$ (to yield 50 to $100 \mu \mathrm{M}$ and 5 to $10 \mu \mathrm{M}$ after $1: 1$ mixing), respectively, in reagent water buffered to the desired $\mathrm{pH}$ with approximately $0.01 \mathrm{M}$ phosphate. These solutions were injected at flow rates ranging from $25-35 \mathrm{~mL} / \mathrm{min}$ from two self-contained Dosimat syringe pumps (Metrohm, Switzerland), through $1.5 \mathrm{~mm}$ I.D. PEEK tubing, and into the inlet ports of a $60^{\circ}$ inner angle PEEK 
mixing tee. The outlet of the mixing tee was connected with a $\sim 7 \mathrm{~cm}$ length of $0.5 \mathrm{~mm}$ I.D. FEP tubing to a $5 \mathrm{~cm}$ flow-through UV-spectrophotometry cell with a cylindrical $3 \mathrm{~mm}$ I.D. optical path. The effluent line of the stopped-flow system was connected via PEEK tubing to a 25 -mL luer-lock gas-tight syringe clamped on to a lab-stand with the needle-side facing down, and the outside end of the piston several centimeters below a fixed metal plate. Effluent from the spectrophotometer cell flowed into the needleend of the syringe until the piston contacted the metal plate - resulting in abrupt stoppage of system flow. Reactions were monitored after stoppage by following decay of $\mathrm{O}_{3}$ at $\lambda=258 \mathrm{~nm}$. The effective deadtime for this system was calculated to be $0.08+0.21=0.29 \sim 0.3 \mathrm{~s}$ (minimum instrument resolution of the spectrophotometer was $0.1 \mathrm{~s}$ ). On the basis of this dead-time, the limit of accurate measurement was estimated to be that for a reaction with $\mathrm{t}_{1 / 2}$ of approximately $0.3 \mathrm{~s}$, or $k_{\mathrm{O}_{3}, \mathrm{obs}}^{\prime} \sim 2.3 \mathrm{~s}^{-1}$. This translated to a practical quantification limit of $k_{\mathrm{O}_{3} \text {,app. }}^{\prime \prime} \sim 4.6 \times 10^{4} \mathrm{M}^{-1} \mathrm{~s}^{-1}$, for [substrate] $]_{0}=50 \mu \mathrm{M}$. The stopped-flow apparatus was calibrated by comparison of the second-order rate constant determined for the neutral species of $\mathrm{RX}\left(k_{\mathrm{O}_{3}, \text { neutral RX }}^{\prime \prime}=1.2( \pm 0.1) \times 10^{7} \mathrm{M}^{-1} \mathrm{~s}^{-1}\right)$ with that reported previously $\left(k_{\mathrm{O}_{3}, \text { neutral } \mathrm{RX}}^{\prime \prime}=1.0( \pm\right.$ 0.1) $\left.\mathrm{x} 10^{7} \mathrm{M}^{-1} \mathrm{~s}^{-1}(35)\right)$, after calculation of the latter value for $\mathrm{p} K_{\mathrm{a}}=9.2(36)\left(\mathrm{a} \mathrm{p} K_{\mathrm{a}}\right.$ of 8.8 was used in the prior study).

Method II ( $\mathrm{O}_{3}$ kinetics): Used for ASMX, CF (pH 3-6), EF (pH 3-5.5), PG, DMI, and FLU (Tables 1 and 2 within the main text). Rate constants for slowly-reacting substrates which absorb strongly at wavelengths close to $258 \mathrm{~nm}$ could not be determined by direct measurement of $\mathrm{O}_{3}$ decay. These rate constants were instead determined under pseudo-first-order conditions of excess $\mathrm{O}_{3}\left(\left[\mathrm{O}_{3}\right]_{0}:[\text { substrate }]_{0} \geq\right.$ 20) by following loss of substrate via HPLC with UV or fluorescence detection. All HPLC analyses were performed on either a Hewlett-Packard 1050 HPLC system equipped with a Supelco Discovery RP Amide C16 column ( $3 \mathrm{~mm} \times 250 \mathrm{~mm}, 5 \mu \mathrm{M})$, fluorescence detector (FLD), and single-wavelength $\mathrm{UV}$ detector, or an Agilent 1100 HPLC system equipped with the same column and a variable wavelength UV diode-array detector. Separations were performed with acetonitrile and $0.05 \mathrm{M} \mathrm{H}_{3} \mathrm{PO}_{4}$ (adjusted to $\mathrm{pH} 2.2$ 
with $\mathrm{NaOH}$ ) as mobile phases, using isocratic or gradient methods as required for the analyte(s) of interest. UV detection was performed at wavelengths from 205 to $280 \mathrm{~nm}$, depending on the analyte (limits of quantification $\cong 0.05 \mu \mathrm{M}$ ). Fluorescence detection was performed at $\lambda_{\text {ex. }}=278 \mathrm{~nm}$ and $\lambda_{\text {em. }}=445$ $\mathrm{nm}$ for $[\mathrm{CF}]_{0}$ and $[\mathrm{EF}]_{0}<1 \mu \mathrm{M}$, and at $\lambda_{\text {ex. }}=278 \mathrm{~nm}$ and $\lambda_{\mathrm{em} .}=360 \mathrm{~nm}$ for $[\mathrm{FLU}]_{0}<1 \mu \mathrm{M}$ (limits of quantification $\cong 0.01 \mu \mathrm{M})$. Standard deviations for each measurement varied from $\pm 1-5 \%$.

Reactions were initiated by injecting - under constant stirring - 10-20-fold excess concentration of $\mathrm{O}_{3}$ into 1-5 $\mu \mathrm{M}$ solutions of substrate contained within 100-mL amber, borosilicate bottles fitted with screw-cap piston-type dispensers (37), and thermostatted by a recirculating water bath. 1-mL samples were subsequently dispensed at pre-determined time intervals into amber, borosilicate HPLC vials containing $25 \mu \mathrm{L}$ of $10 \mathrm{mM}$ cinnamic acid to quench residual $\mathrm{O}_{3}$, and subsequently transferred to HPLC for analysis of residual substrate, $\mathrm{O}_{3}$ (as benzaldehyde (38)), and $p$-chlorobenzoic acid ( $p$ CBA - used as an internal standard used to correct for sample dispensation inaccuracies). Pseudo-first-order rate constants determined from plots of $\ln \left([\mathrm{M}]:[\mathrm{M}]_{0}\right)$ (where $\mathrm{M}$ represents the model substrate) vs. time were linear $\left(r^{2} \geq 0.98\right)$ in all cases. All experiments were conducted in duplicate.

Method III ( $\mathrm{O}_{3}$ kinetics): Used for CP, TET, DAMP, and MBDCH (Tables 1 and 2 within the main text). A number of model substrates included in this study do not significantly absorb UV radiation at wavelengths above $200 \mathrm{~nm}$, are unstable in aqueous solution of extended periods of time, or are difficult to analyze, but react too rapidly with $\mathrm{O}_{3}$ to follow by available manual methods. In each of these cases $\mathrm{O}_{3}$ reaction rate constants were determined by application of a competition kinetics method requiring the measurement of only a single endpoint $\mathrm{P}$, which is typically the formation of a product resulting from oxidation of either the model substrate, M, or competitor substrate, $\mathrm{C}$ (12). Experiments were conducted by adding a fixed dosage of $\mathrm{O}_{3}$ to rapidly-stirred, 20-mL volumes of ten different buffered solutions containing various ratios of $[\mathrm{M}]_{0}:[\mathrm{C}]_{0}$ (both in at least 10-fold molar excess of $\mathrm{O}_{3}$ ). Cinnamic acid $\left(k_{\mathrm{O}_{3}, \text { neutral }}^{\prime \prime}=5 \times 10^{4} \mathrm{M}^{-1} \mathrm{~s}^{-1}\right.$ and $\left.k_{\mathrm{O}_{3} \text {,anion }}^{\prime \prime}=3.8 \times 10^{5} \mathrm{M}^{-1} \mathrm{~s}^{-1}(38), \mathrm{p} K_{\mathrm{a}}=4.4(39)\right)$ or buten-3-ol $\left(k_{\mathrm{O}_{3}}^{\prime \prime}=7.9 \times\right.$ 
$\left.10^{4} \mathrm{M}^{-1} \mathrm{~s}^{-1}(4)\right)$ were used as competitor substrates in these experiments. Yields of benzaldehyde measured by HPLC-UV - or formaldehyde - determined spectrophotometrically at $\lambda=412 \mathrm{~nm}$ as diacetyldihydrolutidine (40) - were selected as respective measurement endpoints, P. Model substrate rate constants were evaluated using eq $\mathrm{S} 1$,

$$
\frac{[\mathrm{P}]_{\text {absence }}}{[\mathrm{P}]_{\text {presence }}}=1+\frac{k_{O_{3}, a p p, C}^{\prime \prime}[\mathrm{C}]_{0}}{k_{O_{3}, a p p, M}^{\prime \prime}[\mathrm{M}]_{0}}
$$

where $[\mathrm{P}]_{\text {absence }}$ represents the measured endpoint yield in the absence of competitor substrate (obtained from duplicate $\mathrm{C}$ controls), and $[\mathrm{P}]_{\text {presence }}$ represents endpoint yield in the presence of varying doses of competitor substrate. $k_{\mathrm{O}_{3}, \text { app }, \mathrm{C}}^{\prime \prime}$ was determined from the slopes of plots of $\frac{[\mathrm{P}]_{\text {absence }}}{[\mathrm{P}]_{\text {presence }}}-1$ vs. $\frac{[\mathrm{C}]_{0}}{[\mathrm{M}]_{0}}$.

Method IV ( $\mathrm{O}_{3}$ kinetics): Used for TYL, SMX, TMP, CF (pH 6.5-8), EF (pH 6-8), VM, APMS, and TMT (Tables 1 and 2 within the main text). A competition kinetics method requiring the measurement of two-endpoints was used to determine $k_{\mathrm{O}_{3} \text {,app }}^{\prime \prime}$ for substrates with $k_{\mathrm{O}_{3} \text {,app }}^{\prime \prime}>5 \times 10^{3} \mathrm{M}^{-1} \mathrm{~s}^{-1}$ that absorb UV radiation strongly at wavelengths above $200 \mathrm{~nm}$ (35). In this approach, a different $\mathrm{O}_{3}$ dose was added to each of ten rapidly-stirred, $20-\mathrm{mL}$ volumes of a buffered solution containing a fixed ratio of $[\mathrm{M}]_{0}:[\mathrm{C}]_{0}$. The two endpoints - residual reference substrate (cinnamic acid) and competitor substrate concentrations remaining after $\mathrm{O}_{3}$ addition - were measured by HPLC-UV. Model substrate rate constants were evaluated according to eq $\mathrm{S} 2$,

$\ln \left(\frac{[C]}{[C]_{0}}\right)=\ln \left(\frac{[M]}{[M]_{0}}\right) \frac{k_{O_{3}, \text { app }, C}^{\prime \prime}}{k_{O_{3}, a p p, M}}$

where $k_{\mathrm{O}_{3}, \text { app,C }}^{\prime \prime}$ could be determined from the slope of a plot of $\ln \left(\frac{[C]}{[C]_{0}}\right)$ vs. $\ln \left(\frac{[M]}{[M]_{0}}\right)$. $[\mathrm{M}]_{0}$ and $[\mathrm{C}]_{0}$ were taken from analyses of duplicate $\mathrm{O}_{3}$ controls included in each experiment. 
Method $V(\bullet O H$ kinetics $):$ Used for RX, AZ, ASMX, TMP, LM, PG, CP, and VM. $\bullet \mathrm{OH}$ rate constants were determined for photo-stable model substrates via application of the same competition kinetics approach as utilized for Method IV, except that eq S2 was modified to eq S3.

$\ln \left(\frac{[C]}{[C]_{0}}\right)=\ln \left(\frac{[p C B A]}{[p C B A]_{0}}\right) \frac{k_{\cdot O H, a p p, C}^{\prime \prime}}{k_{\cdot O H, a p p, p C B A}^{\prime \prime}}$

Hydroxyl radicals were generated by in situ UV-photolysis of $\mathrm{H}_{2} \mathrm{O}_{2}$ in solutions containing the reference substrate $p$-chlorobenzoic acid ( $p$ CBA, with $k_{\bullet O H, a p p, p C B A}^{\prime \prime}=5.0 \times 10^{9} \mathrm{M}^{-1} \mathrm{~s}^{-1}(41)$ ), and competitor substrate, C, according to a previously described procedure (35). Briefly, reaction solutions buffered at pH 7 with approximately $0.01 \mathrm{M}$ phosphate were dosed with $2 \mathrm{mM} \mathrm{H}_{2} \mathrm{O}_{2}$, and fixed $[\mathrm{C}]_{0}:[\mathrm{pCBA}]_{0}$. These solutions were irradiated with a 500-W medium pressure lamp $(\lambda<308 \mathrm{~nm}$ screened by a UV-cutoff filter) for repeated ten-minute intervals up to two-hour total irradiation periods. Samples were withdrawn from these solutions between each irradiation period for residual substrate analysis by HPLC-UV. RX, $\mathrm{AZ}$, and LM were detected at $\lambda=205 \mathrm{~nm}$. Experiments included a minimum of 10 different irradiation times. $\mathrm{H}_{2} \mathrm{O}_{2}$ controls were included in all experiments.

Method VI $(\bullet \mathrm{OH}$ kinetics $):$ Used for TET, TYL, CF, and EF. These substrates were moderately to highly photo-labile in the presence of UV radiation passing the $308 \mathrm{~nm}$ cutoff filter used in Method V. - OH rate constants were determined for these substrates according to the same competition kinetics procedure used in Method V (i.e., via eq S3), but using $\gamma$-radiolysis (42) to generate $\bullet \mathrm{OH}$ in solutions containing each of the model substrates and $p$ CBA. Experiments included at least eight different irradiation times $(\bullet \mathrm{OH}$ exposures$)$.

Method VII $(\bullet \mathrm{OH}$ kinetics $)$ : Used for AM. The $\bullet \mathrm{OH}$ rate constant for AM was determined according to Method V, except that AM was derivatized with 9-fluoroenylmethyl chloroformate (FMOC) (43), to permit detection by UV. One-mL samples (containing starting concentrations of $5 \mu \mathrm{M} A M, 5 \mu \mathrm{M} p \mathrm{CBA}$, and $2 \mathrm{mM} \mathrm{H}_{2} \mathrm{O}_{2}$ ) taken from the photo-reaction system described above were dosed into amber, 
borosilicate HPLC vials containing $25 \mathrm{mM}$ of sodium pyruvate to quench residual $\mathrm{H}_{2} \mathrm{O}_{2}(44)-$ which appeared to interfere with the derivatization process - and $25 \mathrm{mM}$ of $\mathrm{NaOH}$ (to prevent losses of $\mathrm{AM}$ to adsorption onto glass surfaces prior to derivatization (45) and to accelerate the reaction between pyruvate and $\left.\mathrm{H}_{2} \mathrm{O}_{2}(44,46)\right) .500 \mu \mathrm{L}$ of these samples were subsequently transferred to separate HPLC vials containing $500 \mu \mathrm{L}$ of $2.5 \mathrm{mM}$ FMOC in acetonitrile and $200 \mu \mathrm{L}$ of $0.8 \mathrm{M}$ boric acid (to maintain a solution $\mathrm{pH}$ of $\sim 9$ ) for derivatization (43). The remainder of the underivatized samples were used for analysis of residual $p$ CBA by HPLC-UV $(\lambda=205 \mathrm{~nm})$. Derivatized AM was measured by HPLC-UV ( $\lambda$ $=200 \mathrm{~nm})$ a minimum of one hour after initiation of the derivatization reaction $(15$ minute reaction times are reported to be sufficient for derivatization of gentamicin, another aminoglycoside (43)). AM concentrations in dark controls containing $\mathrm{H}_{2} \mathrm{O}_{2}$ were stable over the 135-minute experimental period, indicating that adsorption of AM to reactor tube surfaces was negligible during the period of each experiment.

Text S4. Wastewater matrix experiments.

A 10-L grab sample of secondary wastewater effluent was obtained from the Kloten-Opfikon wastewater treatment facility near Zurich, Switzerland. This sample was transported to the laboratory in a polypropylene carboy within several hours of sampling and vacuum-filtered with a $0.45 \mu \mathrm{m}$ cellulosenitrate membrane prior to storage at $4{ }^{\circ} \mathrm{C}$. Sample alkalinity and DOC were $3.5 \mathrm{mM}$ as $\mathrm{HCO}_{3}^{-}$and $5.3 \mathrm{mg}$ $\mathrm{C} / \mathrm{L}$, respectively. Native sample $\mathrm{pH}$ was 7.7. Kloten-Opfikon secondary wastewater effluent is known to contain - on average - less than $1 \mu \mathrm{g} / \mathrm{L}$ of RX, AZ, SMX, ASMX, and TMP $(47,48)$. The concentration of $\mathrm{CF}$ in the influent to this plant has been reported as $<1 \mu \mathrm{g} / \mathrm{L}$ on average, and should be significantly lower after secondary treatment. These levels are negligible relative to the concentrations spiked to KlotenOpfikon sample for wastewater ozonation experiments, which were $1 \mu \mathrm{M}$ for each substrate (translating to a minimum concentration of $253 \mu \mathrm{g} / \mathrm{L}$, for - SMX - the substrate with the lowest molecular weight). 
Only the reaction between $\mathrm{O}_{3}$ and ASMX was slow enough to permit direct monitoring of ASMX loss during ozonation of the wastewater sample. $63 \mathrm{mM}(3 \mathrm{mg} / \mathrm{L})$ of $\mathrm{O}_{3}$ was added under constant, rapid stirring to a $20-\mathrm{mL}$ volume of Kloten-Opfikon wastewater containing $1 \mu \mathrm{M}$ of ASMX and $1 \mu \mathrm{M}$ of pCBA. Samples were taken every $10 \mathrm{~s}$ until $\mathrm{O}_{3}$ was completely depleted, for subsequent analysis of residual ASMX and pCBA by HPLC-UV.

For all other substrates, various doses of $\mathrm{O}_{3}$ (ranging from $5 \mu \mathrm{M}(0.25 \mathrm{mg} / \mathrm{L})$ to $\left.104 \mu \mathrm{M}(5 \mathrm{mg} / \mathrm{L})\right)$ were added under constant, rapid stirring to $20-\mathrm{mL}$ volumes of Kloten-Opfikon wastewater - each containing $1 \mu \mathrm{M}$ of the model substrate of interest and $1 \mu \mathrm{M}$ of $p \mathrm{CBA}$. Reactions were allowed to proceed until complete $\mathrm{O}_{3}$ depletion (except in the case of solutions dosed with $104 \mu \mathrm{M} \mathrm{O}_{3}$ doses, which were quenched with buten-3-ol after $\sim 90 \mathrm{~s}$ of reaction to remove $\mathrm{O}_{3}$ residual). One-mL samples were then taken from each reaction solution and transferred to amber, borosilicate HPLC vials for direct HPLC-UV analysis of residual model substrate and $p$ CBA concentrations.

Each experiment was conducted in duplicate. In addition, duplicate $\mathrm{O}_{3}$ controls were included with each set of samples to verify substrate stability in the wastewater matrix. Analyte recoveries were calculated from measurements obtained for control samples of distilled water dosed with $1 \mu \mathrm{M}$ concentrations of each substrate, and found to be $100 \pm 10 \%$ for all analytes except TET, for which a recovery of $117 \%$ was recorded. All experiments were conducted at $\mathrm{T}=20 \pm 0.5{ }^{\circ} \mathrm{C}$.

Text S5. Estimation of transformation efficiencies and $\mathrm{f}_{\bullet \mathrm{OH}, \mathrm{M}}$ for $\mathrm{RX}, \mathrm{AZ}, \mathrm{AM}$, and LM

Transformation of a substrate (M) is governed by eq S4 (49) during ozonation of a real water, where the two integral terms on the right hand-side represent the $\mathrm{O}_{3}$ and $\bullet \mathrm{OH}$ exposures governing its conversion $\left(\mathrm{M} / \mathrm{M}_{0}\right)$ for a reaction time, where $[\bullet \mathrm{OH}]=f(\mathrm{t})$ and $\left[\mathrm{O}_{3}\right]=g(\mathrm{t})$.

$\ln \left(\frac{[\mathrm{M}]_{\tau}}{[\mathrm{M}]_{0}}\right)=-k_{\mathrm{O}_{3}, \mathrm{app}, \mathrm{M}}^{\prime \prime} \int_{0}^{\tau}\left[\mathrm{O}_{3}\right] d t-k_{\cdot \mathrm{OH}, \mathrm{app}, \mathrm{M}}^{\prime \prime} \int_{0}^{\tau}[\cdot \mathrm{OH}] d t$ 
The $\bullet \mathrm{OH}$ exposure term, $\int_{0}^{\tau}[\bullet \mathrm{OH}] d t$, can be calculated by using an $\mathrm{O}_{3}$-recalcitrant compound such as pCBA as a probe to measure in situ $\bullet \mathrm{OH}$ exposures, according to eq S5 $(49,50)$. Theoretically, such an

$$
\int_{0}^{\tau}[\bullet \mathrm{OH}] d t=-\frac{1}{k_{\cdot \mathrm{OH}, \mathrm{app}, p \mathrm{CBA}}} \ln \left(\frac{[p \mathrm{CBA}]_{\tau}}{[p \mathrm{CBA}]_{0}}\right)
$$

approach should also be applicable to determining relative $\mathrm{O}_{3}$ exposures for substrates with $k_{\mathrm{O}_{3} \text {,app }}^{\prime \prime}>10^{3}$ $\mathrm{M}^{-1} \mathrm{~s}^{-1}$ during ozonation processes; i.e., one should be able to determine $\int_{0}^{\tau}\left[\mathrm{O}_{3}\right] d t$ for a certain probe compound and use this value to estimate $\ln \left(\frac{[\mathrm{M}]_{\tau}}{[\mathrm{M}]_{0}}\right)$ for other substrates exposed to the same reaction conditions. However, unlike $\bullet \mathrm{OH}$ exposure, $\mathrm{O}_{3}$ exposure can only be calculated indirectly from eqs $\mathrm{S} 4$ and $\mathrm{S} 5$ (via eq $\mathrm{S} 6$ ), since no $\bullet \mathrm{OH}$-refractory, $\mathrm{O}_{3}$-susceptible probe compound is available to provide an in situ measurement of this value.

$$
\int_{0}^{\tau}\left[\mathrm{O}_{3}\right] d t=\left(\frac{k_{\cdot \mathrm{OH}, \mathrm{app}, \mathrm{M}}^{\prime \prime}}{k_{\cdot \mathrm{OH}, \mathrm{app}, \mathrm{CBA}}} \ln \left(\frac{[p \mathrm{CBA}]_{\tau}}{[p \mathrm{CBA}]_{0}}\right)-\ln \left(\frac{[\mathrm{M}]_{\tau}}{[\mathrm{M}]_{0}}\right)\right) / k_{\mathrm{O}_{3}, \mathrm{app}, \mathrm{M}}^{\prime \prime}
$$

The applicability of this approach was evaluated by calculating $\ln \left(\frac{[\mathrm{M}]_{\tau}}{[\mathrm{M}]_{0}}\right)$ (at $\mathrm{O}_{3}$ dosages of 1 and 1.5 $\mathrm{mg} / \mathrm{L}$ ) for each of the nine substrates TYL, SMX, TMP, CF, EF, CP, PG, TET, and VM, by using each of the $\int_{0}^{\tau}\left[\mathrm{O}_{3}\right] d t$ terms determined with eq S6 for the other eight substrates. $\int_{0}^{\tau}[\bullet \mathrm{OH}] d t$ was calculated for each substrate according to eq S5. As shown in Figure S13, this procedure yielded good estimates of transformation efficiencies, $\ln \left(\frac{[\mathrm{M}]_{\tau}}{[\mathrm{M}]_{0}}\right)$, as long as $\int_{0}^{\tau}\left[\mathrm{O}_{3}\right] d t$ terms were selected from the $\int_{0}^{\tau}\left[\mathrm{O}_{3}\right] d t$ value measured for the substrate with the most similar $k_{\mathrm{O}_{3} \text {,app }}^{\prime \prime}$ at the wastewater $\mathrm{pH}$ of 7.7 (e.g., PG transformation was estimated on the basis of $\mathrm{CF}$ transformation, $\mathrm{EF}$ transformation from TMP 
transformation, and TET transformation from TYL transformation). In contrast, significant discrepancies were observed when estimates were based on $\int_{0}^{\tau}\left[\mathrm{O}_{3}\right] d t$ obtained from substrates with markedly different magnitudes of $k_{\mathrm{O}_{3} \text {,app }}^{\prime \prime}$ (i.e., differing by more than one order of magnitude from each other). Estimates of $\ln \left(\frac{[\mathrm{M}]_{\tau}}{[\mathrm{M}]_{0}}\right)$ for RX, AZ, AM, and LM were obtained by using the $\int_{0}^{\tau}\left[\mathrm{O}_{3}\right] d t$ terms for TMP, SMX, CF, and TYL, respectively. These estimates were in turn used to calculate $f_{\cdot \mathrm{oH}, \mathrm{M}}$ by eq 6 in the main text (see Figure 4 in the main text).

The discrepancies noted above - for $\ln \left(\frac{[\mathrm{M}]_{\tau}}{[\mathrm{M}]_{0}}\right)$ estimates based on comparison of substrate pairs with dissimilar $k_{\mathrm{O}_{3} \text {,app }}^{\prime \prime}$ values - may have been a consequence of incomplete mixing on the time-scales of initial $\mathrm{O}_{3}$ consumption in each reaction system. Since initial consumption of $\mathrm{O}_{3}$ by wastewater matrixes such as that utilized here is typically extremely rapid ( $\mathrm{t}_{1 / 2}$ on the order of 0.01 to $\left.0.05 \mathrm{~s}\right)(51)$, such a mixing effect may have resulted in disproportionate $\mathrm{O}_{3}$ consumption by locally abundant sample matrix constituents (relative to very small local concentrations of the given antibacterial substrate) within the vicinity of $\mathrm{O}_{3}$ injection. This could have resulted in lower observed transformation of substrates than predicted on the basis of their $\mathrm{O}_{3}$ rate constants alone. Estimation errors would be more pronounced for substrate pairs exhibiting large differences in $k_{\mathrm{O}_{3} \text {,app }}^{\prime \prime}$ (i.e., $>$ two orders of magnitude), as indicated above. 
Table S1. $\mathrm{p} K_{\mathrm{a}}$ values and corresponding source references for each antibacterial substrate

\begin{tabular}{|c|c|c|c|c|c|c|c|}
\hline Structural Class & Substrate* $^{*}$ & $\mathrm{p} K_{\mathrm{a} 1}$ & $\mathrm{p} K_{\mathrm{a} 2}$ & $\mathrm{p} K_{\mathrm{a} 3}$ & $\mathrm{p} K_{\mathrm{a} 4}$ & $\mathbf{p} K_{\mathrm{a} 5}$ & $\mathrm{p} K_{\mathrm{a} 6}$ \\
\hline \multirow[t]{3}{*}{ Macrolide } & $\mathrm{RX}$ & $9.2(36)$ & & & & & \\
\hline & $\mathrm{AZ}$ & $8.7(52)$ & $9.5(52)$ & & & & \\
\hline & TYL & $7.7(52)$ & & & & & \\
\hline \multirow[t]{2}{*}{ Sulfonamide } & SMX & $1.7(53)$ & $5.6(53)$ & & & & \\
\hline & ASMX & $5.5(54)$ & & & & & \\
\hline \multirow[t]{2}{*}{ Fluoroquinolone } & $\mathrm{CF}$ & $6.2(55)$ & $8.8(55)$ & & & & \\
\hline & $\mathrm{EF}$ & $6.1(56)$ & $7.7(56)$ & & & & \\
\hline DHFR Inhibitor & TMP & $\begin{array}{l}3.2 \\
(36,57,58)\end{array}$ & $7.1(58)$ & & & & \\
\hline Lincosamide & LM & $7.8(36)$ & & & & & \\
\hline \multirow[t]{2}{*}{$\beta$-lactam } & PG & $2.7(59)$ & & & & & \\
\hline & $\mathrm{CP}$ & $2.5(60)$ & $7.1(60)$ & & & & \\
\hline Tetracycline & TET & $3.3(61)$ & $7.7(61)$ & $9.7(61)$ & & & \\
\hline Glycopeptide & VM & $2.9(62,63)$ & $\begin{array}{l}7.2 \\
(62,63)\end{array}$ & $\begin{array}{l}8.6 \\
(62,63)\end{array}$ & $9.6(62)$ & $10.5(62)$ & $11.7(62)$ \\
\hline Aminoglycoside & AM & $6.7(64)$ & $8.4(64)$ & $8.4(64)$ & $9.7(64)$ & & \\
\hline
\end{tabular}

*For full names, see Table 1 in the main text

Table S2. $\mathrm{p} K_{\mathrm{a}}$ values and corresponding source references for each substructure model substrate

\begin{tabular}{ll} 
Substrate $^{a}$ & $\mathbf{p} \boldsymbol{K}_{\mathrm{a} 1} \quad \mathbf{p}_{\mathrm{a} 2}$ \\
\hline DMCH & $10.7(65)$ \\
MP & $10.2(66)$ \\
APMS & $1.5(67)$ \\
DMI & NA \\
EPC & $8.3(68)$ \\
FLU & $6.5(69)$ \\
DAMP & $3.2^{b}$ \\
TMT & NA \\
MBDCH & $3.5(66)$ \\
CH & $10.6(65)$ \\
CHM & $10.3(66)$ \\
\hline NA - Not applicable. ${ }^{a}$ For full names, see Table 2 in the main text. ${ }^{b} K_{\mathrm{a}}$ values assumed to approximate those for TMP, since \\
DAMP is identical to TMP's 2,4-diamino-5-methylpyrimdine moiety.
\end{tabular}


Table S3. Second-order rate constants $\left(\mathrm{M}^{-1} \mathrm{~s}^{-1}\right)$ for reactions of $\mathrm{O}_{3}$ with substructure model substrates

\begin{tabular}{|c|c|c|c|}
\hline $\begin{array}{l}\text { Substrate }^{a} \\
\text { (Rate } \\
\text { constant } \\
\text { measurement } \\
\left.\text { methods }^{b}\right)\end{array}$ & Diprotonated & $\begin{array}{c}k_{\mathrm{O}_{3}}^{\prime \prime}{ }^{c} \\
\text { Species } \\
\text { Monoprotonated }\end{array}$ & Deprotonated \\
\hline DMCH (I) & NA & $<1^{d}$ & $3.7( \pm 0.1) \times 10^{6}$ \\
\hline MP (I) & NA & $<1^{d}$ & $2.0( \pm 0.1) \times 10^{6}$ \\
\hline APMS (IV) & NA & ND & $4.7( \pm 0.1) \times 10^{4}$ \\
\hline DMI (II) & NA & NA & $5.4( \pm 0.3) \times 10^{1}$ \\
\hline EPC (I) & NA & $<1^{d}$ & $1.1( \pm 0.1) \times 10^{6}$ \\
\hline FLU (II) & NA & $1.2( \pm 0.7)$ & $1.8( \pm 0.1) \times 10^{3}$ \\
\hline DAMP (III) & $5.0( \pm 12) \times 10^{2}$ & $2.9( \pm 1.3) \times 10^{3}$ & $1.3( \pm 0.2) \times 10^{6}$ \\
\hline TMT (IV) & NA & NA & $2.8( \pm 0.1) \times 10^{5}$ \\
\hline MBDCH (III) & NA & ND & $1.4( \pm 0.4) \times 10^{6}$ \\
\hline $\mathrm{CH}(\mathrm{I})$ & NA & $<1^{d}$ & $4.9( \pm 0.2) \times 10^{4}$ \\
\hline CHM (I) & NA & $<1^{d}$ & $7.1( \pm 0.2) \times 10^{4}$ \\
\hline
\end{tabular}

NA - Not applicable, ND - Not determined. ${ }^{a}$ For full names, see Table 2 in the main text. ${ }^{b}$ Described in Text S3. ${ }^{c} \mathrm{O}_{3}$ reaction rate constants were measured at $\mathrm{T}=20 \pm 0.5^{\circ} \mathrm{C}$. ${ }^{d}$ These rate constants were assumed to be negligible, on the basis of prior observations for protonated amine reaction centers $(2,24)$. 


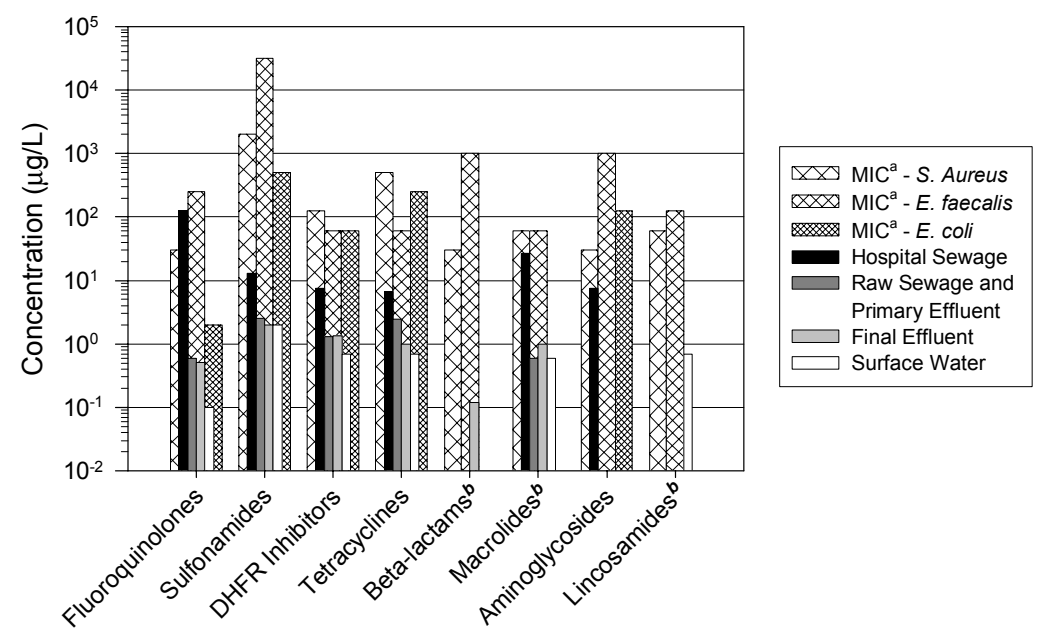

Figure S1. Maximum single-compound* concentrations of various antibacterial classes detected in municipal wastewater systems and surface waters, in the context of minimum reported clinical MIC values for sensitive bacterial reference strains. Data for fluoroquinolones (70-76), sulfonamides (48, 7278), DHFR (dihydrofolate reductase) inhibitors $(72,73,75-77,79,80)$, tetracyclines $(72,73,80), \beta$-lactams (81), macrolides $(29,48,73,74,76,82)$, aminoglycosides (83), and lincosamides (73) was obtained from various environmental analytical studies. ${ }^{a} \mathrm{MIC}$ - minimal inhibitory concentration, or minimal concentration resulting in a measurable reduction in bacterial growth relative to an antibacterial blank. MICs listed for each class correspond (in order from left to right) to reported values for ciprofloxacin, sulfamethoxazole, trimethoprim, tetracycline, penicillin, erythromycin, gentamicin, and clindamycin, respectively $(10),{ }^{b} \mathrm{MIC}$ values not reported for $E$. coli. *More than one compound from a given antibacterial class may be present in the same municipal wastewater.

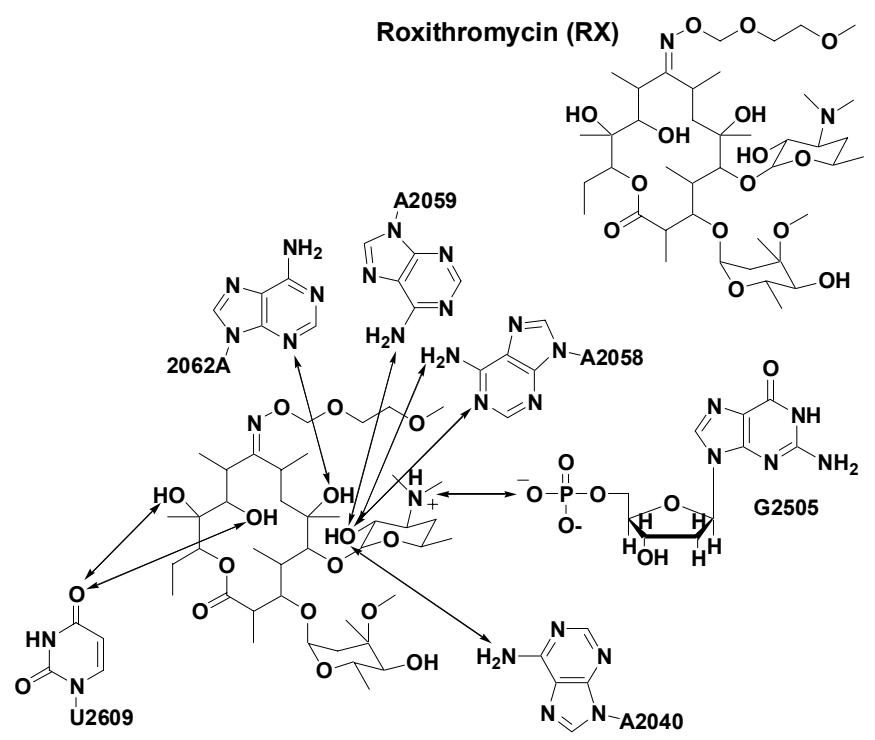

Figure S2. Biochemical model for mechanism of macrolide antibacterial activity (adapted with permission from Schlünzen et al. (1)). 


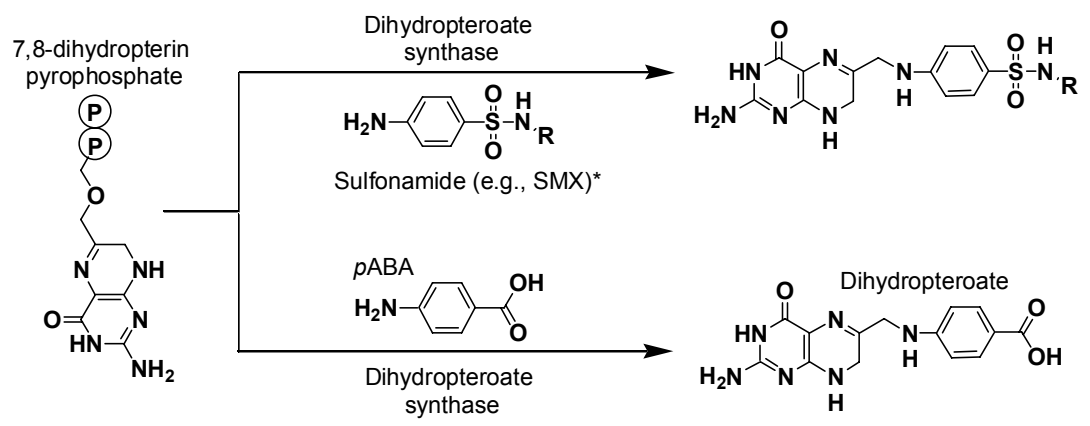

Figure S3. Biochemical mechanism of sulfonamide antibacterial activity (5). * $\mathrm{R}$ represents an aromatic substituent that varies, depending on the particular sulfonamide compound.

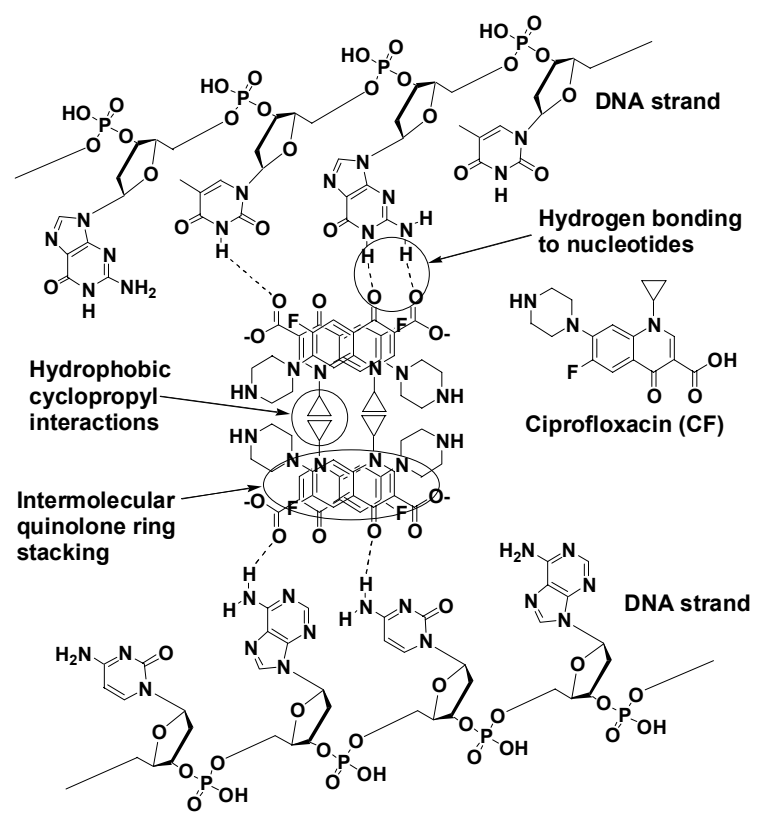

Figure S4. Biochemical model for mechanism of fluoroquinolone antibacterial activity (adapted with permission from Shen et al. (8)).

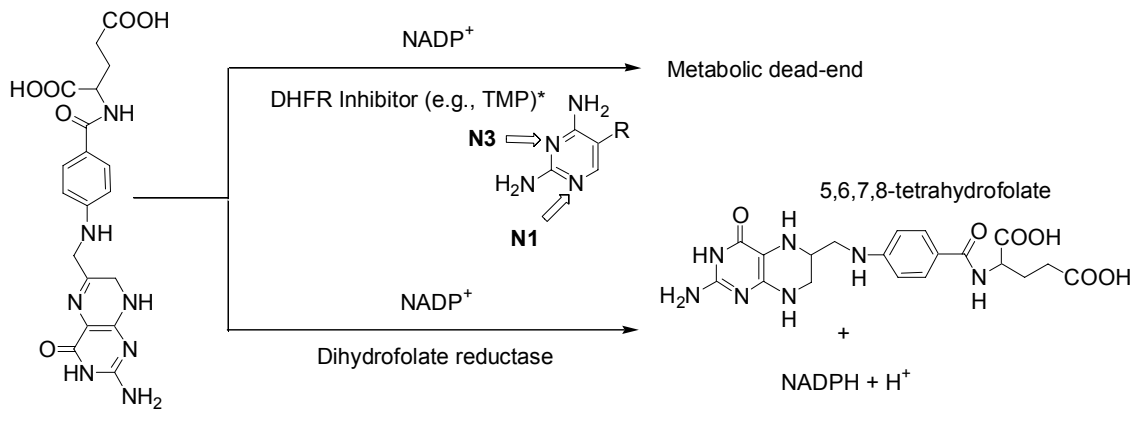

7,8-dihydrofolate

Figure S5. Biochemical mechanism of dihydrofolate reductase (DHFR) inhibitor antibacterial activity (5). *R represents an aromatic substituent that varies, depending on the particular DHFR inhibitor. 


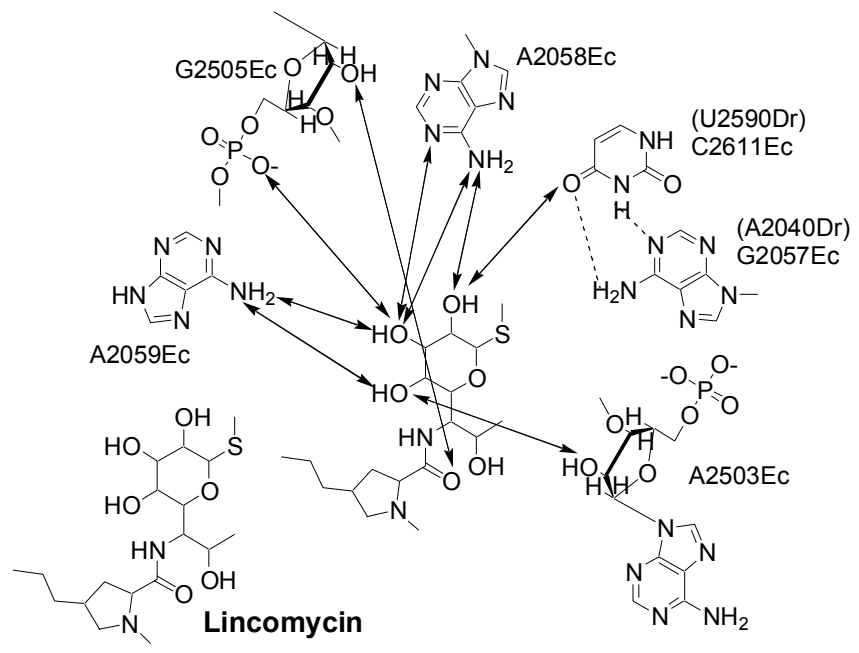

Figure S6. Biochemical model for mechanism of lincosamide antibacterial activity (adapted with permission from Schlünzen et al. (1)).

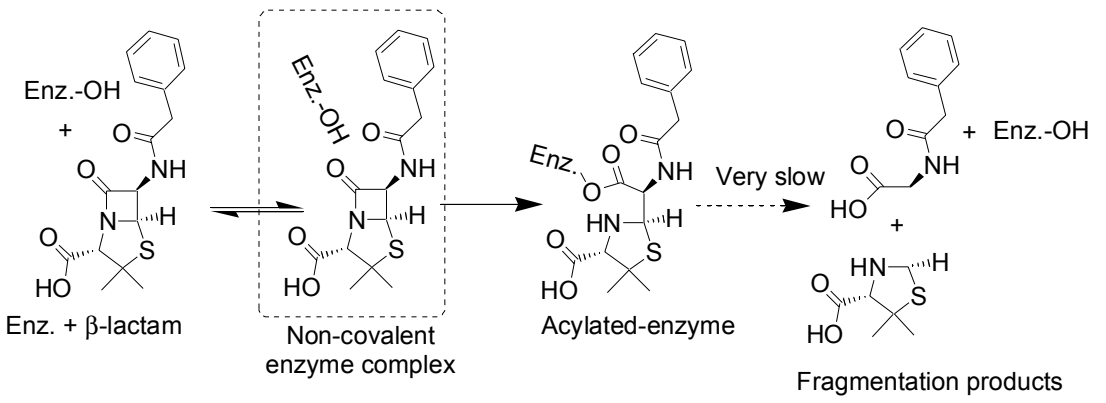

Figure S7. Biochemical mechanism of $\beta$-lactam antibacterial activity (depicted for penicillin G) $(5,16)$.

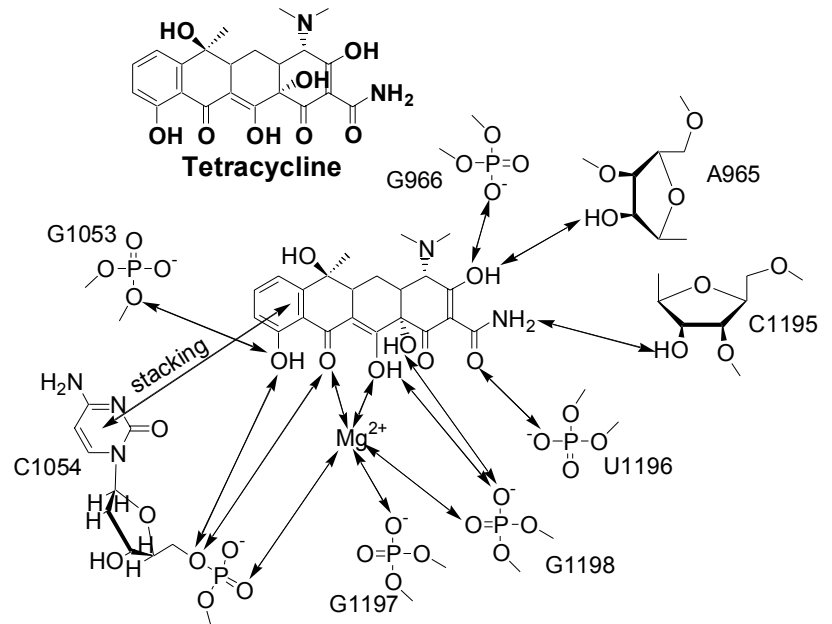

Figure S8. Biochemical model for primary* mechanism of tetracycline antibacterial activity (adapted with permission from Broderson et al. (20)). *Tetracycline binding at a secondary site within the bacterial ribosome is believed to involve many of the same functional moieties as binding at the primary site (20). 


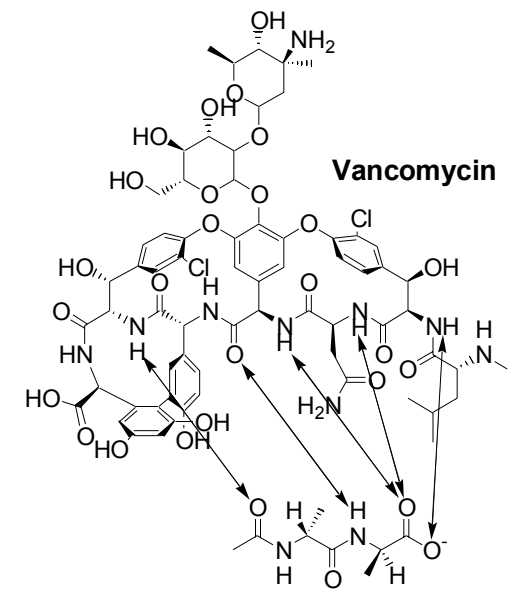

Figure S9. Biochemical model for mechanism of glycopeptide antibacterial activity (adapted with permission from Williams and Bardsley (1999) (23)).

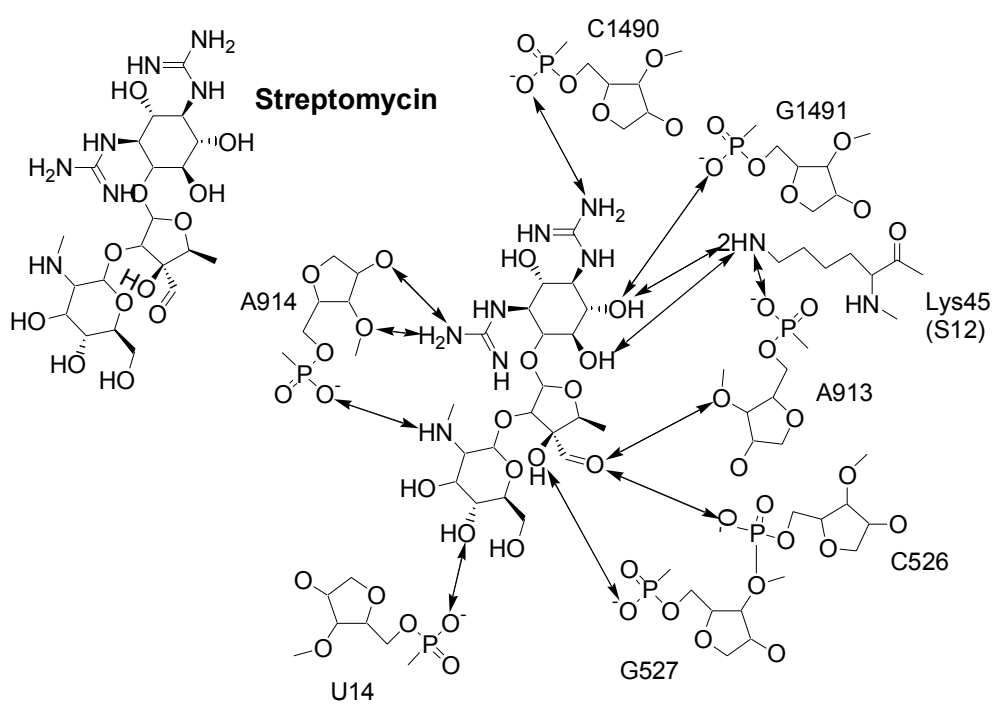

Figure S10. Biochemical model for mechanism of aminoglycoside antibacterial activity (adapted with permission from Carter et al. (27)). 


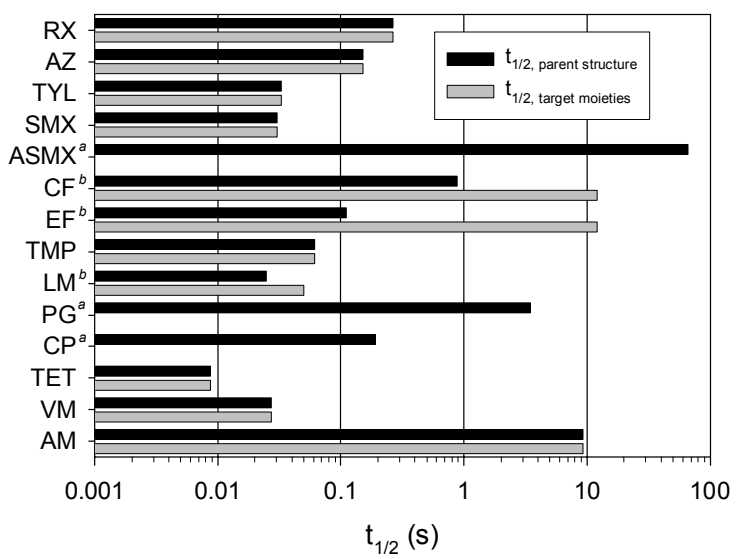

Figure S11. Calculated $\mathrm{t}_{1 / 2}$ values for the apparent transformation of model antibacterial substrates by $\mathrm{O}_{3}$, in comparison to corresponding estimated half-lives for reaction of $\mathrm{O}_{3}$ with the targeted functional moieties (Table 1 in the main text) associated with each substrate's biochemical activity at $20( \pm 0.5){ }^{\circ} \mathrm{C}$, $\mathrm{pH} 7$, and $\left[\mathrm{O}_{3}\right]=42 \mu \mathrm{M}(2 \mathrm{mg} / \mathrm{L})$. ${ }^{a}$ Either $\mathrm{O}_{3}$ does not appear to react directly with biochemically-active target moieties (PG, CP), or $\mathrm{t}_{1 / 2}$ for this reaction could not be determined (ASMX). ${ }^{b} \mathrm{t}_{1 / 2 \text {,target }}$ estimates for $\mathrm{CF}$ and $\mathrm{EF}$ are based on the $\mathrm{t}_{1 / 2}$ value determined for FLU and $t_{1 / 2, \text { target }}$ for LM based on $\mathrm{t}_{1 / 2}$ determined for cationic LM, as discussed in the main text.

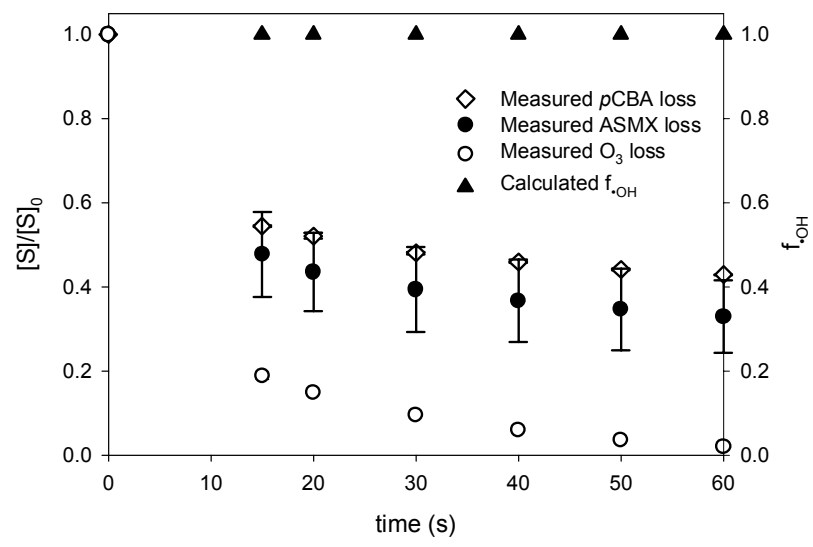

Figure S12. Transformation of ASMX during ozonation of Kloten-Opfikon wastewater at $20( \pm 0.5){ }^{\circ} \mathrm{C}$, $\mathrm{pH} 7.7,\left[\mathrm{O}_{3}\right]_{0}=63 \mu \mathrm{M}(3 \mathrm{mg} / \mathrm{L})$, and $[\text { substrate }]_{0}=1 \mu \mathrm{M}$. S represents each monitored substance $-\mathrm{O}_{3}$, $p \mathrm{CBA}$, and ASMX. 


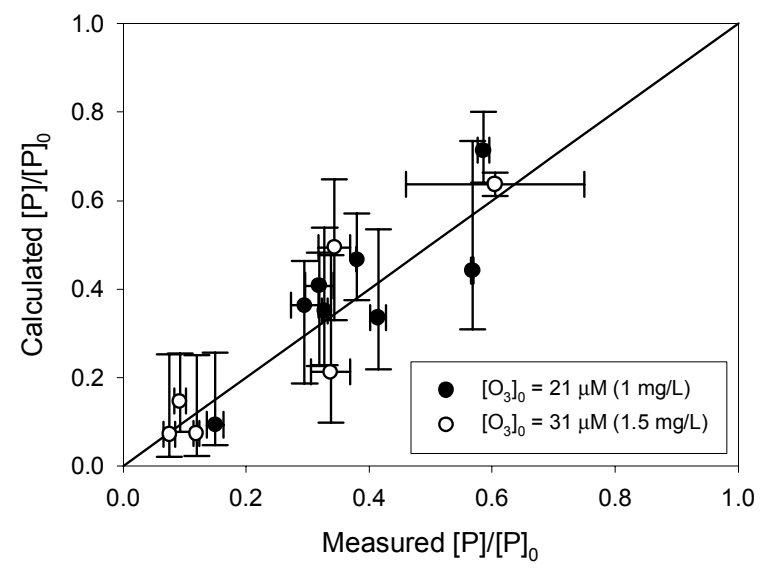

Figure S13. Correlations of predicted substrate transformation with measured values, for data sets obtained at $\mathrm{T}=20^{\circ} \mathrm{C}$, pH 7.7, and $\left[\mathrm{O}_{3}\right]_{0}=1$ and $1.5 \mathrm{mg} / \mathrm{L}(21$ and $31 \mu \mathrm{M}$, respectively).

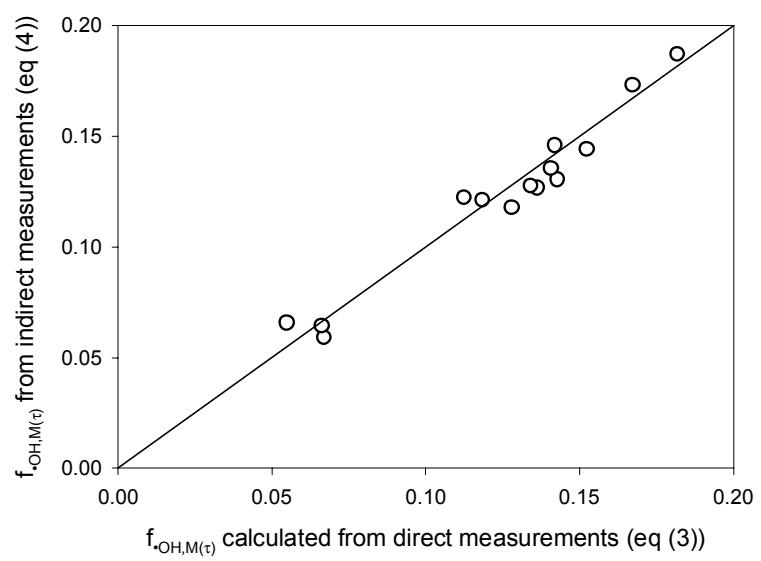

Figure S14. Comparison of $\mathrm{f}_{{ }_{\mathrm{OH}, \mathrm{M}(\tau)}}$ values calculated from indirect determinations of $\mathrm{O}_{3}$ exposure (by eq 6 in the main text) with those calculated from direct measurements of $\mathrm{O}_{3}$ exposure (by eq 4 in the main

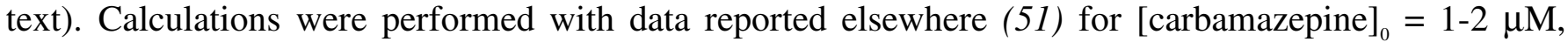
$\left[\mathrm{O}_{3}\right]=25-50 \mu \mathrm{M}(1.2-2.4 \mathrm{mg} / \mathrm{L})$, in various municipal wastewater samples. 


\section{Literature Cited}

1. Schlünzen, F.; Zarivach, R.; Harms, J.; Bashan, A.; Tocilj, A.; Albrecht, R.; Yonath, A.; Franceschi, F., Structural basis for the interaction of antibiotics with the peptidyl transferase centre in eubacteria. Nature 2001, 413, 814-821.

2. Hoigné, J.; Bader, H., Rate constants of reactions of ozone with organic and inorganic compounds in water - II : Dissociating organic compounds. Water Res. 1983, 17, 185-194.

3. Muñoz, F.; von Sonntag, C., The reactions of ozone with tertiary amines including the complexing agents nitrilotriacetic acid (NTA) and ethylenediaminetetraacetic acid (EDTA) in aqueous solution. $J$. Chem. Soc., Perkin Trans. 2 2000, 2029-2033.

4. Dowideit, P.; von Sonntag, C., Reaction of ozone with ethene and its methyl- and chlorine-substituted derivatives in aqueous solution. Environ. Sci. Technol. 1998, 32, 1112-1119.

5. Walsh, C. Antibiotics: Actions, Origins, Resistance; ASM Press: Washington, D.C., 2003.

6. Spanggord, R. J.; Yao, D.; Mill, T., Kinetics of aminodinitrotoluene oxidations with ozone and hydroxyl radical. Environmental Science \& Technology 2000, 34, 450-454.

7. Pierpoint, A. C.; Hapeman, C. J.; Torrents, A., Linear free energy study of ring-substituted aniline ozonation for developing treatment of aniline-based pesticide wastes. J. Agric. Food Chem. 2001, 49, 3827-3832.

8. Shen, L. L.; Mitscher, L. A.; Sharma, P. N.; O'Donnell, T. J.; Chu, D. W. T.; Cooper, C. S.; Rosen, T.; Pernet, A. G., Mechanism of inhibition of DNA gyrase by quinolone antibacterials: a cooperative drug-DNA binding model. Biochemistry 1989, 28, 3886-3894.

9. Theruvathu, J. A.; Flyunt, R.; Aravindakumar, C. T.; von Sonntag, C., Rate constants of ozone reactions with DNA, its constituents, and related compounds. J. Chem. Soc., Perkin Trans. 2 2001, 269-274.

10. Wiedemann, B.; Grimm, H. In Antibiotics in Laboratory Medicine; Lorian, V., Ed.; Williams and Wilkins: Baltimore, MD, 1996; pp 900-1168.

11. Cocco, L.; Roth, B.; Temple, C., Jr.; Montgomery, J. A.; London, R. E.; Blakley, R. L., Protonated state of methotrexate, trimethoprim, and pyrimethamine bound to dihydrofolate reductase. Arch. Biochem. Biophys. 1983, 226, 567-577.

12. Muñoz, F.; von Sonntag, C., Determination of fast ozone reactions in aqueous solution by competition kinetics. J. Chem. Soc., Perkin Trans. 2 2000, 2, 661-664.

13. Spry, D. O., Oxidation of penicillin and dihydrocephalosporin derivatives with ozone. J. Org. Chem. 1972, 37, 793-795.

14. Bailey, P. S. Ozonation in organic chemistry. II. Non-olefinic compounds; Academic Press: New York, NY, 1982. 
15. Sztaricskai, F.; Dinya, Z.; Batta, G.; Mocsári, A., Chemical synthesis and structural study of lincomycin sulfoxides and a sulfone. The Journal of Antibiotics 1997, 50, 866-873.

16. Livermore, D. M.; Williams, J. D. In Antibiotics in Laboratory Medicine; 4 ed.; Lorian, V., Ed.; Williams and Wilkins: Baltimore, MD, 1996; pp 502-578.

17. de Koning, J. J.; Marx, A. F.; Poot, M. M.; Smid, P. M.; Verweij, J. In Recent Advances in the Chemistry of $\beta$-Lactam Antibiotics; Elks, J., Ed.; The Chemical Society: Burlington House, London (England), 1977; Vol. 28, pp 161-166.

18. Torii, H.; Asano, T.; Matsumoto, N.; Kato, K.; Tsushima, S.; Kakinuma, A., Microbial oxidation of cephalosporins to cephalosporin sulfoxides. Agricultural and Biological Chemistry 1980, 44, 14311433.

19. Bailey, P. S. Ozonation in organic chemistry. I. Olefinic compounds; Academic Press: New York, NY, 1978.

20. Brodersen, D. E.; Clemons, W. M., Jr.; Carter, A. P.; Morgan-Warren, R. J.; Wimberly, B. T.; Ramakrishnan, V., The structural basis for the action of the antibiotics tetracycline, pactamycin, and hygromycin B on the 30S ribosomal subunit. Cell 2000, 103.

21. Hoigné, J.; Bader, H., Rate constants of reactions of ozone with organic and inorganic compounds in water - I : Non-dissociating organic compounds. Water Res. 1983, 17, 173-183.

22. Mvula, E.; von Sonntag, C., Ozonolysis of phenols in aqueous solution. Org. Biomol. Chem. 2003, 1, 1749-1756.

23. Williams, D. H.; Bardsley, B., The vancomycin group of antibiotics and the fight against resistant bacteria. Angewandte Chemie-International Edition 1999, 38, 1173-1193.

24. Pryor, W. A.; Giamalva, D. H.; Church, D. F., Kinetics of ozonation. 2. Amino acids and model compounds in water and comparisons to rates in nonpolar solvents. J. Am. Chem. Soc. 1984, 106, 7094-7100.

25. Ragnar, M.; Eriksson, T.; Reitberger, T.; Brandt, P., A new mechanism in the ozone reaction with lignin like structures. Holzforschung 1999, 53, 423-428.

26. von Gunten, U., Ozonation of drinking water: Part I. Oxidation kinetics and product formation. Water Res. 2003, 37, 1443-1467.

27. Carter, A. P.; Clemons, W. M., Jr.; Brodersen, D. E.; Morgan-Warren, R. J.; Wimberly, B. T.; Ramakrishnan, V., Functional insights from the structure of the $30 \mathrm{~S}$ ribosomal subunit and its interactions with antibiotics. Nature 2000, 407, 340-348.

28. Kadurugamuwa, J. L.; Lam, J. S.; Beveridge, T. J., Interaction of gentamicin with the A band and B band lipopolysaccharides of Pseudomonas aeruginosa and its possible lethal effect. Antimicrob. Agents Chemother. 1993, 37, 715-721.

29. Göbel, A.; McArdell, C. S.; Suter, M. J.-F.; Giger, W., Trace determination of macrolide and sulfonamide antimicrobials, a human sulfonamide metabolite, and trimethoprim in wastewater using 
liquid chromatography coupled to electrospray tandem mass spectrometry. Anal. Chem. 2004, 76, 4756-4764.

30. Bader, H.; Hoigné, J., Determination of ozone in water by the indigo method. Water Res. 1981, 15, 449-456.

31. Hoigné, J.; Bader, H., The role of hydroxyl radical reactions in ozonation processes in aqueous solutions. Water Res. 1976, 10, 377-386.

32. Staehelin, J.; Hoigné, J., Decomposition of ozone in water in the presence of organic solutes acting as promoters and inhibitors of radical chain reactions. Environ. Sci. Technol. 1985, 19, 1206-1213.

33. Mosseri, S.; Neta, P.; Meisel, D., The mechanism of cyanide release in the radiolysis of acetonitrile. Formation and decay of the cyanomethylperoxyl radical. Radiat. Phys. Chem. 1990, 36, 683-687.

34. Schwarzenbach, R. P.; Gschwend, P. M.; Imboden, D. M. Environmental Organic Chemistry; 2 ed.; John Wiley \& Sons, Inc.: Hoboken, NJ, 2003.

35. Huber, M. M.; Canonica, S.; Park, G.-Y.; von Gunten, U., Oxidation of pharmaceuticals during ozonation and advanced oxidation processes. Environ. Sci. Technol. 2003, 37, 1016-1024.

36. Qiang, Z. M.; Adams, C., Potentiometric determination of acid dissociation constants (pK(a)) for human and veterinary antibiotics. Water Res. 2004, 38, 2874-2890.

37. Hoigné, J.; Bader, H., Characterization of water-quality criteria for ozonation processes. 2. Lifetime of added ozone. Ozone-Science \& Engineering 1994, 16, 121-134.

38. Leitzke, A.; Reisz, E.; Flyunt, R.; von Sonntag, C., The reactions of ozone with cinnamic acids: formation and decay of 2-hydroperoxy-2-hydroxyacetic acid. J. Chem. Soc., Perkin Trans. 2 2001, 793-797.

39. Lide, D. R., Ed. CRC Handbook of Chemistry and Physics; 82 ed.; CRC Press: Boca Raton, FL, 2001.

40. Nash, T., The colorimetric estimation of formaldehyde by means of the Hantzsch reaction. Biochem. J. 1953, 55, 416-421.

41. Buxton, G. V.; Greenstock, W. P.; Helman, W. P.; Ross, A. B., Critical review of rate constants for reactions of hydrated electrons, hydrogen atoms, and hydroxyl radicals $\left(\cdot \mathrm{OH} / \bullet \mathrm{O}^{-}\right)$in aqueous solution. J. Phys. Chem. Ref. Data 1988, 17, 513.

42. Von Gunten, U.; Oliveras, Y., Advanced oxidation of bromide-containing waters: Bromate formation mechanisms. Environmental Science \& Technology 1998, 32, 63-70.

43. Stead, D. A.; Richards, R. M. E., Sensitive fluorimetric detection of gentamicin sulfate in biological matrices using solid-phase extraction, pre-column derivatization with 9-fluoroenylmethyl chloroformate and reversed phase high-performance liquid chromatography. Journal of Chromatography B 1996, 675, 295-302.

44. Bunton, C. A., Oxidation of $\alpha$-diketones and $\alpha$-keto acids by hydrogen peroxide. Nature 1949, 163, 444. 
45. Josephson, L.; Houle, P.; Haggerty, M., Stability of dilute aqueous solutions of gentamicin and tobramycin. Clinical Chemistry 1979, 25, 298-300.

46. Siegel, B.; Lanphear, J., Kinetics and mechanisms for the acid-catalyzed oxidative decarboxylation of benzylformic acid. J. Org. Chem. 1979, 44, 942-946.

47. Golet, E. M.; Alder, A. C.; Giger, W., Environmental exposure and risk assessment of fluoroquinolone antibacterial agents in wastewater and river water of the Glatt Valley watershed, Switzerland. Environ. Sci. Technol. 2002, 36, 3645-3651.

48. Göbel, A.; Thomsen, A.; McArdell, C. S.; Joss, A.; Giger, W., Occurrence and sorption behavior of sulfonamides, macrolides, and trimethoprim in activated sludge treatment. Environmental Science \& Technology 2005, 39, 3981-3989.

49. Elovitz, M. S.; von Gunten, U., Hydroxyl radical/ozone ratios during ozonation processes. I. The $\mathrm{R}_{\mathrm{ct}}$ concept. Ozone Sci. Eng. 1999, 21, 239-260.

50. Huber, M. M.; Göbel, A.; Joss, A.; Hermann, N.; Löffler, D.; McArdell, C. S.; Ried, A.; Siegrist, H.; Ternes, T. A.; von Gunten, U., Oxidation of pharmaceuticals during ozonation of municipal wastewater effluents: a pilot study. Environ. Sci. Technol. 2005, 39, 4290-4299.

51. Buffle, M.-O.; Schumacher, J.; Salhi, E.; von Gunten, U., Measurement of the initial phase of ozone decomposition in water and wastewater by means of a continuous quench flow system: Application to disinfection and pharmaceutical oxidation. Water Res. 2005, Accepted for publication.

52. McFarland, J. W.; Berger, C. M.; Froshauer, S. A.; Hayashi, S. F.; Hecker, S. J.; Jaynes, B. H.; Jefson, M. R.; Kamicker, B. J.; Lipinski, C. A.; Lundy, K. M.; Reese, C. P.; Vu, C. B., Quantitative structureactivity relationships among macrolide antibacterial agents: In Vitro and in Vivo potency against Pasteurella multocida. J. Med. Chem. 1997, 40, 1340-1346.

53. Lucida, H.; Parkin, J. E.; Sunderland, V. B., Kinetic study of the reaction of sulfamethoxazole and glucose under acidic conditions I. Effect of pH and temperature. Int. J. Pharm. 2000, 202, 47-61.

54. Rieder, J., Physikalisch-chemische und biologische Untersuchungen an Sulfonamiden. 1. Mitteilung: Pharmakologisch interessante physikalisch-chemische Merkmale von 21 Sulfonamiden und 6 Sulfonamid-Metaboliten. Arzneim.-Forsch. 1963, 13, 81-88.

55. Vázquez, J. L.; Berlanga, M.; Merino, S.; Domènech, Ò.; Viñas, M.; Montero, M. T.; HernándezBorrell, J., Determination by fluorimetric titration of the ionization constants of ciprofloxacin in solution and in the presence of liposomes. Photochem. Photobiol. 2001, 73, 14-19.

56. Barbosa, J.; Barrón, D.; Jiménez-Lozano, E.; Sanz-Nebot, V., Comparison between capillary electrophoresis, liquid chromatography, potentiometric, and spectrophotometric techniques for evaluation of $\mathrm{pK}_{\mathrm{a}}$ values of zwitterionic drugs in acetonitrile-water mixtures. Analytica Chimica Acta 2001, 437, 309-321.

57. Riand, J.; Chenon, M. T.; Lumbrosobader, N., Proton and C-13 Nuclear Magnetic-Resonance Studies of Substituted Pyrimidines .2. Monoprotonation of Methylpyrimidines and Aminopyrimidines. J. Am. Chem. Soc. 1977, 99, 6838-6845. 
58. Roth, B.; Strelitz, J. Z., The Protonation of 2,4-Diaminopyrimidines. I. Dissociation Constants and Substituent Effects. J. Org. Chem. 1969, 34, 821-836.

59. Rapson, H. D. C.; Bird, A. E., Ionisation constants of some penicillins and of their alkaline and penicillinase hydrolysis products. J. Pharm. Pharmacol. 1963, 15, T222-T231.

60. Takács-Novák, K.; Box, K. J.; Avdeef, A., Potentiometric $\mathrm{p} K_{\mathrm{a}}$ determination of water-insoluble compounds: validation study in methanol/water mixtures. Int. J. Pharm. 1997, 151, 235-248.

61. Stephens, C. R.; Murai, K.; Brunings, K. J.; Woodward, R. B., Acidity constants of tetracycline antibiotics. J. Am. Chem. Soc. 1956, 78, 4155-4158.

62. Nieto, M.; Perkins, H. R., Physicochemical properties of vancomycin and iodovancomycin and their complexes with diacetyl-L-lysyl-D-alanyl-D-alanine. Biochem. J. 1971, 123, 773-\&.

63. Antipas, A. S.; Vandervelde, D.; Stella, V. J., Factors affecting the deamidation of vancomycin in aqueous-solutions. Int. J. Pharm. 1994, 109, 261-269.

64. Kane, R. S.; Glink, P. T.; Chapman, R. G.; McDonald, J. C.; Jensen, P. K.; Gao, H.; Pasa-Tolic, L.; Smith, R. D.; Whitesides, G. M., Basicity of the amino groups of the aminoglycoside amikacin using capillary electrophoresis and coupled CE-MS-MS techniques. Anal. Chem. 2001, 73, 4028-4036.

65. Christensen, J. J.; Izatt, R. M.; Wrathall, D. P.; Hansen, L. D., Thermodynamics of proton ionization in dilute aqueous solution. Part XI. pK, $\Delta H^{\circ}$, and $\Delta S^{\circ}$ values for proton ionization from protonated amines at $25^{\circ}$. Journal of the Chemical Society A: Inorganic, Physical, Theoretical 1969, 1212-1223.

66. Weber, E. J.; Kenneke, J. F. SPARC (http://www.epa.gov/athens/research/projects/sparc). US EPA, National Exposure Research Laboratory: Athens, GA.

67. Pankratov, A. N.; Uchaeva, I. M.; Doronin, S. Y.; Chernova, R. K., Correlations between the basicity and proton affinity of substituted anilines. J. Struct. Chem. 2001, 42, 739-746.

68. Hall, H. K., Jr., Potentiometric determination of the base strengths of amines in non-protolytic solvents. J. Phys. Chem. 1956, 60, 63-70.

69. Barbosa, J.; Barrón, D.; Cano, J.; Jiménez-Lozano, E.; Sanz-Nebot, V.; Toro, I., Evaluation of electrophoretic method versus chromatographic, potentiometric, and absorptiometric methodologies for determining $\mathrm{p} K_{\mathrm{a}}$ values of quinolones in hydroorganic mixtures. J. Pharm. Biomed. Anal. 2001, 24, 1087-1098.

70. Hartmann, A.; Golet, E. M.; Gartiser, S.; Alder, A. C.; Koller, T.; Widmer, R. M., Primary DNA damage but not mutagenicity correlates with ciprofloxacin concentrations in German hospital wastewaters. Arch. Environ. Contam. Toxicol. 1999, 36, 115-119.

71. Golet, E. M.; Xifra, I.; Siegrist, H.; Alder, A. C.; Giger, W., Environmental exposure assessment of fluoroquinolone antibacterial agents from sewage to soil. Environ. Sci. Technol. 2003, 37, 3243-3249.

72. Lindberg, R.; Jarnheimer, P.-Å.; Olsen, B.; Johansson, M.; Tysklind, M., Determination of antibiotic substances in hospital sewage water using solid phase extraction and liquid chromatography/mass spectrometry and group analogue internal standards. Chemosphere 2004, 57, 1479-1488. 
73. Kolpin, D. W.; Furlong, E. T.; Meyer, M. T.; Thurman, E. M.; Zaugg, S. D.; Barber, L. B.; Buxton, H. T., Pharmaceuticals, hormones, and other organic wastewater contaminants in U.S. Streams, 19992000: A national reconnaissance. Environ. Sci. Technol. 2002, 36, 1202-1211.

74. Miao, X.-S.; Bishay, F.; Chen, M.; Metcalfe, C. D., Occurrence of antimicrobials in the final effluents of wastewater treatment plants in Canada. Environ. Sci. Technol. 2004, 38, 3542-3550.

75. Renew, J. E.; Huang, C.-H., Simultaneous determination of fluoroquinolone, sulfonamide, and trimethoprim antibiotics in wastewater using tandem solid phase extraction and liquid chromatography-electrospray mass spectrometry. J. Chromatogr., A 2004, 1042, 113-121.

76. Ohlsen, K.; Ternes, T. A.; Werner, G.; Wallner, U.; Löffler, D.; Wilma, Z.; Witte, W.; Hacker, J., Impact of antibiotics on conjugational resistance gene transfer in Staphylococcus aureus in sewage. Environ. Microbiol. 2003, 5, 711-716.

77. Hirsch, R.; Ternes, T. A.; Haberer, K.; Kratz, K.-L., Occurrence of antibiotics in the environment. Sci. Tot. Environ. 1999, 225, 109-118.

78. Hartig, C.; Storm, T.; Jekel, M., Detection and identification of sulphonamide drugs in municipal waste water by liquid chromatography coupled with electrospray ionisation tandem mass spectrometry. J. Chromatogr., A 1999, 854, 163-173.

79. Metcalfe, C. D.; Miao, X.-S.; Koenig, B. G.; Struger, J., Distribution of acidic and neutral drugs in surface waters near sewage treatment plants in the lower Great Lakes, Canada. Environ. Toxicol. Chem. 2003, 22, 2881-2889.

80. Lindberg, R. H.; Wennberg, P.; Johansson, M. I.; Tysklind, M.; Andersson, B. A. V., Screening of human antibiotic substances and determination of weekly mass flows in five sewage treatment plants in Sweden. Environmental Science \& Technology 2005, 39, 3421-3429.

81. Andreozzi, R.; Caprio, V.; Ciniglia, C.; de Champdoré, M.; lo Giudice, R.; Marotta, R.; Zuccato, E., Antibiotics in the environment: occurrence in Italian STPs, fate, and preliminary assessment on algal toxicity of amoxicillin. Environ. Sci. Technol. 2004, 38, 6832-6838.

82. McArdell, C. S.; Molnar, E.; Suter, M. J. F.; Giger, W., Occurrence and fate of macrolide antibiotics in wastewater treatment plants and in the Glatt Valley Watershed, Switzerland. Environmental Science \& Technology 2003, 37, 5479-5486.

83. Löffler, D.; Ternes, T. A., Analytical method for the determination of the aminoglycoside gentamicin in hospital wastewater via liquid chromatography-electrospray-tandem mass spectrometry. $J$. Chromatogr., A 2003, 1000, 583-588. 